\title{
On the Role of College English Teaching in Quality Education
}

\author{
Qiutan $\mathrm{Yu}^{\mathrm{a}}$ \\ Feixian Campus, Linyi University, Linyi, Shandong, China \\ a fxyuqiutan@126.com
}

Keywords: college English teaching; quality-based education; college English education; function.

\begin{abstract}
College English teaching is an indispensable component of quality-based education, and the under-standing of this relationship between them is the very point at which the reform of college English teaching should start. Hence, college English education, instead of merely the teaching of language skills, should also be a goal at which teachers of college English aim. Unfortunately, however, not enough attention has ever been paid to it in the history of college English teaching. Cognition, cultural competence, subject awareness and affect are all educational factors of great importance that need to be taken into consideration by the teacher of college English. In doing so, the teacher might be able to help the students attain all-round development.
\end{abstract}

\section{Introduction}

At present, there seems to be a tendency in the teaching of college English, that is, to introduce the traditional teaching theory and method to the traditional teaching. The theories and methods of criticism to the college English teaching injured all over the body, as a language skill training class pure. Indeed, the language skills training as a specific target not altogether inexcusable in college English teaching, its rationality cannot be doubted, however, should not be the same. It is doubtful that as an integral part of education, the teaching of college English is the same as other branches of education, and it also has educational merit. For a long time, in the teaching concept and practice of people, the teaching and education of college English and its branches are closely related. The department has not received its due attention, which leads to college English teaching, which is often dissociated from educational research. We can always be able to college English. Teaching takes delight in learning, but rarely touches and even thinks about "College English education". College English teaching has made brilliant achievements after decades of efforts, but its teaching effect is always unsatisfactory. One of the important reasons is probably because of college English teaching.

\section{College English Teaching Plays an Important Role in Developing Students' Intelligence and Improving Their Cognitive Ability}

In fact, teaching method, teaching method is. Any kind of teaching theory and method has its rationality, but the emphasis is different. The key is: 1) the introduction of the teaching theories and methods don't go to extremes; 2) to see whether it is suitable for our teaching practice. We should see that in College English teaching is different from the children's language acquisition, but also different from the second language learning. College English learning motivation, learning environment, there is a big difference of learning psychology and educational background and the first two cases different. Heard teaching language, not to teach language knowledge it is difficult to adapt to the reality of China's college English teaching. It now appears that learning a foreign language in the domestic conditions, through the study of grammar and a lot of practice to grasp foreign language, is still the main way, but you should make extensive contact and use of language learners, in a large number of language practice activities by analogy, induction of language acquisition process effectively. It is effective for the basic guiding ideology of foreign language teaching to. In English as a foreign language learning situation, whether adopt what kind of concept, path and the method, have a cognitive problem. There is no reason to believe that language training at the same time cannot be the pursuit of an intelligence target, make learners have a conceptual grasp of 
the language and culture. Plan for language learning and use needs of learners, expectations and rules of recognition that is a perceptual development, memory training, deepen the thinking process. The average intelligence can be considered as basic ability of people, including observation, attention, thinking. In the cultivation of college English teaching language skills and communication skills at the same time, with the development of intelligence, improve cognitive ability.

College English teaching requires students not only to acquire language skills, but also learn about language and culture knowledge. There is no reason why the language and cultural knowledge general learning will be boring; instead it can further stimulate students' interest in language, perception and comparison of similarities and differences between English and Chinese and explore the general rules of the language. College English teaching through reading and listening, say, write, translation skills training, can cultivate students' observation, language and distinction the social and cultural phenomenon, the collection, storage, sorting, extracting linguistic and cultural information, and found that the application of correction rules, to solve the problems found, reasoning and other aspects of the can force. For example, memorizing words is a matter for many students to worry about, because memorizing foreign words and memorizing language rings of native words. The phonetic knowledge and word formation are particularly important. Comparison and association are also memory sheets. Words are often used effectively. These rules, knowledge and methods can be obtained in part by teachers, but it is also necessary. The students inspired by teachers to observe their own, find, sorting and correction. These psychological activities will promote the continuous development of students' cognitive ability. Students can also get from learning English to knowledge, experience and methods applied to the learning of other subjects, the so-called migration. As the enhancement of the cognitive abilities the purpose of foreign language teaching, in accordance with the principle of knowledge and understanding about the relation between education, it will make the language course add a new and valuable level, to strengthen and will not affect the language proficiency training.

\section{College English Teaching Has the Role of Improving Students' Cultural Quality and Enhancing Their Communicative Competence}

Cultural competence refers to the understanding of the behavior norms, customs and values of a society. Language is the carrier of human culture, while learning language will naturally increase cultural knowledge. In recent years, language and the rise of the study of cultural relations, the issue of cultural introduction in college English teaching has also aroused the attention of college English workers. It is pointed out that English is not only a tool for exchanging information, but also helps the learners broaden their horizons, broaden their knowledge and deepen the external world. The understanding, learn and absorb the essence of foreign culture, improve their cultural literacy. College English listening textbooks with cultural notes after each listening text. Many teachers in teaching students to introduce western culture, compare the differences between Chinese and Western culture, so as to improve the cultural ability of students. The integration of cultural competence into communicative competence is equivalent to the appropriateness of communicative competence principle. It mainly refers to non-verbal social and cultural behaviors and facts. Communicative competence depends not only on language competence, but also on cultural competence. If there is no knowledge about culture, if we do not understand cultural acceptability and unacceptable ability. If we take the communicative competence as the training objective, then it should take college English in the social cultural environment. Some people even suggest that cultural competence should be taught in language training skills, it is not without reason. The college English classroom for students to understand and accept the alien culture provides a position; culture introduction has added a new dimension to college English teaching, enrich college English classroom teaching.

Of course, we emphasize the cultivation of cultural quality, and we should also pay attention to the practice of college English teaching. After all, college English teaching is the same. In order to help students to make a good foundation of language, our emphasis should also be the mastery of language 
form and the cultivation of language skills. The introduction of knowledge should be selected and should be centered around the cultivation of language ability.

\section{College English Teaching Has the Role of Enhancing Students' Subjective Consciousness and Exerting Their Main Role.}

There are many valuable things in our traditional educational thought, but many of them are afraid that it is difficult to adapt to the development of the times. As required, the healthy development of education is restricted. In the relationship between teachers and students in the classroom teaching, we seem to have stressed respect for the teacher. If we can change an angle to consider respect student. Respect teacher, we emphasize the importance of knowledge and teachers as the dignity of the elderly, but it must not be equated with the teacher's dignity. The classroom teacher-student relationship is equal, are active participants in the exchange of information from the language teaching, teachers and students are subjects, is to teach and learn language subject. Subject status and role of teachers and students in English teaching, is a question concerning the overall situation, is the starting point of modern foreign language teaching. English teaching should rise to the quality of the training and the overall height, link quality education, should become the modern education provided by the people-oriented college English education. Foreign language teaching cannot be simply interpreted as I teach you. the teacher's dignity should not be in the foreign language classroom rules.

In fact, our students are lack of consciousness, largely due to the traditional sense of the teachers too. We respect and rely on students there will be a teacher, students in the psychological, which brings difficulties to the classroom communication between teachers and students. The teacher-student relationship is equal, complementary and mutually dependent. The teacher is not of course guidance, but the classroom communication activities of the organizers, is to help students who facilitator. The students are not passive recipients of information, but should actively participate in classroom activities, to participate in the evaluation of classroom teaching. Teachers should encourage students to find problems and this timely response, their observation and thinking on language motivation, help them to find the law of language. Outline also pointed out that the student is the main body of teaching. To teach the knowledge to be understood by the students, absorption, practice students rely on the ability. Students should be active learning really.

\section{College English Teaching Has the Role of Cultivating Students' Positive Language Culture and Language Learning Emotion and Improving Their Aesthetic Ability.}

As early as the early twentieth century, the importance of affect in education began to attract attention. Educators began to emphasize the role of education of the emotions, but the role of emotion in foreign language education didn't get attention until 1970s.For the English learners, English is a new system of symbols and knowledge, and the mother tongue. There is a great difference. In the course of learning, learners are bound to be accompanied by a variety of emotions, and may find English very interesting, it may also feel strange in English; it may show a feeling of love, or a perplexity; it may soon be recognized. And the acceptance of English, may also show a dislike of English, and even refuses. For the society and culture of the English nation, the learners also. One of the important tasks of college English teaching is to help the learners to set up a positive attitude. To be, to contact and identify the society and culture of the English language, because the society and culture of the target language are negative, even the culture. It is an attitude of refusal. It is probably difficult and impossible to learn the language well. It is not to say that the learners are not criticized. Therefore, college English teachers have the responsibility to help students to form a correct judgment. Do not disparage and reject English and the culture that it reflects, and do not blindly worship it.

Because of the extensive use of English and its importance as an international language, it is also due to the reform and opening up of our country and the economic construction. As a matter of need, English has a high position in our country, and English learning is highly valued. The attitude of 
nation and culture is positive, which provides a good teaching environment for college English teaching. Such as the English learning experience in the middle school stage, the learning motivation after entering the university, the experience of college English learning, and the effect of the stage of learning. Teaching methods, classroom teaching is not efficiency, this will dampen the enthusiasm of students. Furthermore, teachers must also have the correct teaching attitude, full enthusiasm and high tolerance and patience. Such teachers can exaggerate the atmosphere and influence students. Foreign language learning is not good. It may be accomplished overnight. Difficulties in learning are unavoidable. Good students will have a positive attitude and thirst for learning language. Make good psychological preparation, face the difficulties and setbacks in the learning process, and form the ability to study independently and continue to study.

As a result, college English teaching to a certain extent it is boring, teachers feel tired, it is difficult to get all-round development of students, physical and mental health were affected by the society for college English teaching effects were not satisfactory. Only the idea of change. The reform of teaching practice, in order to make the College English teaching role in quality education really play.

\section{References}

[1]. College English syllabus (revised) [Z]. Shanghai: Shanghai Foreign language Education Press, Beijing: higher Education Press, 1999.

[2]. Stern H. Issues and Options in Language Teaching [M]. Shanghai: Shanghai Foreign language Education Press.

[3]. Zhu Jun. Psychology of foreign language teaching [M]. Shanghai: Shanghai Foreign language Education Press, China.

[4]. Hu Chundong, Wang Cairen. Communication in English Teaching [M]. Nanning: Guangxi Education Press, 1998.

[5]. Xia Jimei. Adhering to an objective and practical approach to College English Teaching $[\mathrm{J}]$.Foreign language Teaching in 1999: 4: 31- 37. 